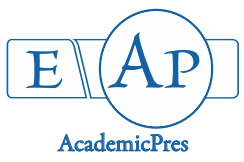

Solanki V et al. (2021)

Notulae Scientia Biologicae

Volume 13, Issue 3, Article number 11030

DOI: $10.15835 / \mathrm{nsb} 1311030$

Research Article

\title{
Persistence, dissipation and health risk assessment of combi-product profenofos and cypermethrin in/on sapota under sub-tropical agro-climatic conditions in India
}

\author{
Vanrajsinh SOLANKI ${ }^{1}$, Susheel SINGH ${ }^{1 *}$, Rohan KANSARA ${ }^{1}$, \\ Kelvin GANDHI ${ }^{1}$, Nitisha PATEL ${ }^{1}$, Timur AHLAWAT ${ }^{2}$
}

\author{
${ }^{1}$ Navsari Agricultural University, Food Quality Testing Laboratory, Navsari 396450, \\ Gujarat,India; vnrj26@gmail.com; susheelsingh@nau.in (*corresponding author); rohankansara1988@gmail.com; \\ kelvingandhi89@gmail.com; nitishapatel210@gmail.com \\ ${ }^{2}$ Navsari Agricultural University, National Agricultural Higher Education Project (NAHEP), Centre for Advanced Agricultural \\ Science and Technology (CAAST), Navsari 396450, Gujarat, India; tahlawat4@nau.in
}

\begin{abstract}
Sapota, a prominent and economically important fruit crop of India is susceptible to several species of insect and mite pests. Several pesticides formulations are used to control the pest damage in sapota. The present investigation was aimed to study the dissipation and persistence behaviour of combi-product profenofos $40 \%$ + cypermethrin $4 \%(44 \mathrm{EC})$ at the standard dose (SD) $\left(1162 \mathrm{~g}\right.$ a.i. $\mathrm{ha}^{-1}+106 \mathrm{~g}$ a.i. ha $\left.{ }^{-1}\right)$ and double to standard dose $(2 \times \mathrm{SD})\left(2324 \mathrm{~g}\right.$ a.i. ha ${ }^{-1}+212 \mathrm{~g}$ a.i. $\left.\mathrm{ha}^{-1}\right) \mathrm{in} /$ on sapota under tropical agro-climatic conditions of South Gujarat in India. Prior to quantitative analysis of pesticide residue on Gas chromatography with electron captured detector (GC-ECD), the modified Quick, Easy, Cheap, Effective, Rugged and Safe (QuEChERS) based method was validated on its accuracy, precision, linearity and sensitivity. Profenofos persisted in sapota up to 30 days with the half-lives of 5.65 and 7.34 days at $\mathrm{SD}$ and $2 \times \mathrm{SD}$, respectively. Cypermethrin dissipated at a rapid pace and was below quantitation limit (BQL) on 7 days at either dose of application; the half-life values recorded were 3.27 and 4.43 days at $S D$ and $2 \times S D$, respectively. This is the first case study that reflects 14 days as a waiting period after the last spray of combi-product (44EC) at standard dose facilitates the residuefree sapota fruits. Further, the health risk index $(\mathrm{HRI}<1)$ and Health Index $(\mathrm{HI} \%<100 \%)$ indicates that the application of combi-product profenofos $40 \%+$ cypermethrin $4 \%$ (44EC) at standard dose could not pose any health risk to Indian consumers.
\end{abstract}

Keywords: cypermethrin; dissipation; health risk assessment; profenofos; sapota

\section{Introduction}

Sapota (Manilkara achras Mill.) is one of the important tropical fruit crops cultivated in all agroecological zones of India (Shirol et al., 2009; Ghosh, 2014). Globally, India is considered to be the major producer of sapota with an area of about 99 thousand ha with a production of 1236 thousand metric tonnes (National Horticultural Board, 2018). In India, Sapota is widely cultivated with thousand tonnes production

Received: 16 Jul 2021. Received in revised form: 27 Jul 2021. Accepted: 09 Aug 2021. Published online: 18 Aug 2021. From Volume 13, Issue 1, 2021, Notulae Scientia Biologicae journal uses article numbers in place of the traditional method of continuous pagination through the volume. The journal will continue to appear quarterly, as before, with four annual numbers. 
in top states i.e., Gujarat (326.36), Karnataka (315.38), Tamil Nadu (169.96), Maharashtra (134.78) and Andhra Pradesh (131.46) during year 2017-18 (National Horticultural Board, 2019).

Conventionally, sapota was considered to be a hardy species that needs little attention of farmers for controlling the pests and diseases. However, this belief is changing due to monoculture of the sapota in recent past in India. Due to the monoculture of the crop, sapota trees are ravaged by several species of insect and mite pests throughout the year because of the monoculture of sapota (Shukla et al., 2011). Sapota is infested by more than 25 insect pests which include bud borer, sapota moth, midrib folder, leaf miner, fruit flies, sucking pests etc. (Butani, 1979; Jhala et al., 1986; Ujagir, R. and Byrne, 2009; Thumar et al., 2015).

Several insecticides are used to control the damage of insects-pests in sapota production in different tropical regions of India. Several pesticide combination products are available in the market and it is choice of the farmers for the control of pest damage in sapota. Combination product (Profenofos $40 \%+$ Cypermethrin $4 \%$ ) is preferred by the farmers to check the losses caused due to the attack of bud borer and sapota borer. This product provides contact and stomach as well as a knockdown effect over a period of time. Though, the combiproduct is invariably used by the farmers in sapota but, its persistence and dissipation behaviour are not available. Therefore, the prime objective of this experiment was to study the behaviour of the pre-mixed product of Profenofos and Cypermethrin in/on sapota and its risk assessment. This foremost report will help the scientific fraternity as well as farmers and consumers to avoid the pesticide residue in sapota.

\section{Materials and Methods}

\section{Chemicals and reagents}

The reference standard of profenofos (purity, 96.9\%) and cypermethrin (purity, 99.8\%) were procured from Sigma-Aldrich India Ltd., Bangalore (Figure 1). The pre-mix formulation of profenofos + cypermethrin (44EC) was purchased from a local market. Primary secondary amines (PSA) were purchased from Supelco Sigma Aldrich (Germany). HPLC grade reagents and solvents were used for pesticide residue analysis. The stock solution was prepared with $n$-hexane: acetone $(9: 1, \mathrm{v} / \mathrm{v})$ and then diluted to prepare the intermediate and working standards and then stored at $-20^{\circ} \mathrm{C}$, were also protected from light.

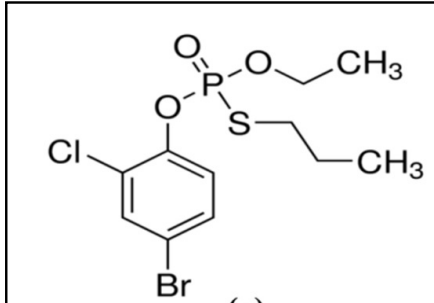

(a)

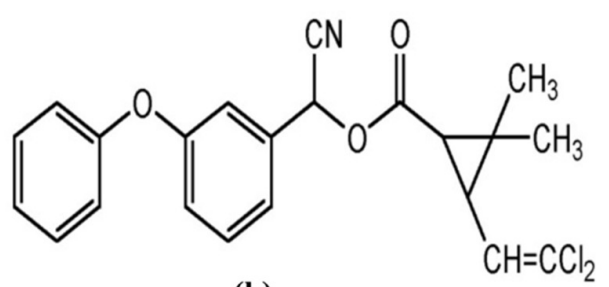

(b)

Figure 1. Chemical structure of (a) profenofos and (b) cypemethrin

\section{Apparatus}

Samples were processed using heavy-duty variable speed homogenizer (SRK Instruments, Gujarat), centrifuge (Eppendorf, Germany) and Turbovap (Caliper life science, PerkinElmer USA). A gas chromatograph (Trace GC Ultra ${ }^{\circ}$ ) with ECD detector and TRIPLUS auto-sampler AI 1310 (Thermo Fisher, USA) was used for pesticide residues analysis. 


\section{Field experiment}

The study was carried out at Regional Horticultural Research Station, Navsari Agricultural University, Navsari, Gujarat, India using sapota variety, kalipatti under tropical agro-climatic conditions of India during year 2017-18. The farm is located at $20^{\circ} 55^{\prime} 18.11^{\prime \prime} \mathrm{N}$ and $72^{\circ} 53^{\prime} 27.47^{\prime \prime} \mathrm{E}$ at an altitude of about $10 \mathrm{~m}$ above mean sea level (MSL) (Figure 2). According to agro-climatic condition, Navsari is situated under South Gujarat heavy rainfall zone-I (Agro-ecological situation-III). Minimum and maximum temperature varies from $17^{\circ} \mathrm{C}$ to $22^{\circ} \mathrm{C}$ and $31^{\circ} \mathrm{C}$ to $36^{\circ} \mathrm{C}$ with an average annual rainfall about $1400-1800 \mathrm{~mm}$. The soil of the experimental field was clay in texture having $\mathrm{pH} 7.5-8.3, \mathrm{EC} 0.3-0.6 \mathrm{dS} \mathrm{m}^{-1}$ and organic carbon content of 0.6-0.68\%.

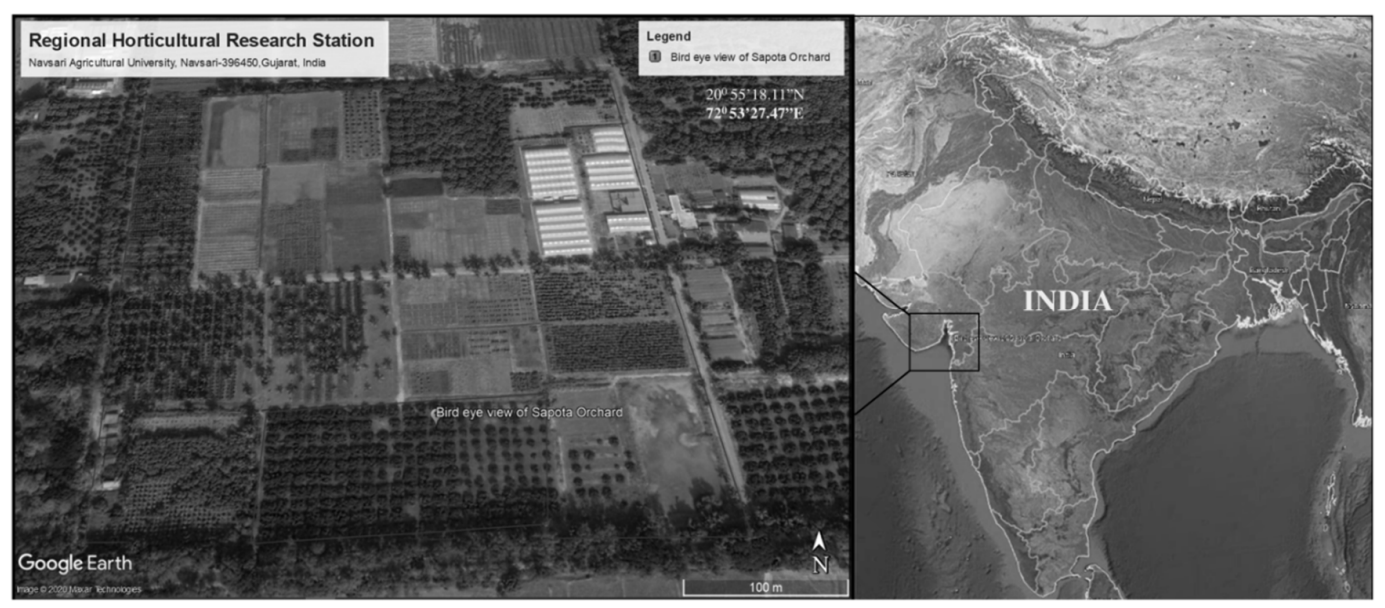

Figure 2. Map of the Sapota fruit and soil sampling area

Total eleven rows consist of 10 sapota trees spaced apart $(5 \mathrm{~m} \times 5 \mathrm{~m})$ were selected and three rows were allotted for each treatment and one buffer row was left in between two treatments to check the effect of spray drift. The treatments applied were control (spray of water), standard dose SD e.g.1268 g a.i. ha ${ }^{-1}$ (Profenofos $1162+$ cypermethrin $106 \mathrm{~g}$ a.i./ha) and double to the standard dose $(2 \times \mathrm{SD})$ e.g. $2536 \mathrm{~g}$ a.i. ha ${ }^{-1}$ (Profenofos 2324+ Cypermethrin $212 \mathrm{~g}$ a.i./ha) (Suryavanshi and Patel, 2009). The spray volume was taken 15 liters per tree and applied with the help of Maruti Foot Sprayer on the second fortnight of February when the major flush of fruits was harvested. The sapota fruits were collected on $0(2 \mathrm{~h}), 1,3,5,7,10,20,30$ and 45 days after the application of pesticides. Approximately 3 to 4 fruits (about $200 \mathrm{~g}$ ) were harvested from each tree and composited to get $2 \mathrm{~kg}$ samples from each treatment and carried to the laboratory for processing to determine the persistence of profenofos and cypermethrin residue in/on sapota fruit.

\section{Sample processing}

The unripe medium sized sapota fruits (24 units) were collected, rinsed, dried and homogenized for the residue analysis of profenofos and cypermethrin. The soil samples were collected on 0 and 30 days after the last application. Approximately $2 \mathrm{~kg}$ of soil samples were collected from 10 sampling sites from each treatment with standard sampling procedure. Prior to analysis, soil samples were mixed thoroughly, air dried milled and passed through $2 \mathrm{~mm}$ sieve and then subjected to pesticide residues analysis. Extraction and clean-up of profenofos and cypermethrin residues in sapota fruits and soil were carried out according to QuEChERS method with certain modifications (Sharma, 2013; Solanki et al., 2019).

\section{Sample extraction and cleanup procedure}

(a) Sapota: Homogenized sapota samples $(15 \pm 0.1 \mathrm{~g})$ were extracted in $50 \mathrm{~mL}$ capacity polypropylene centrifuge tube with $15 \mathrm{~mL}$ acetonitrile having $1 \%$ of acetic acid and put it into deep freeze for 20 minutes. 
Subsequently, $6.0 \mathrm{~g}$ of magnesium sulphate (anhydrous) and $1.5 \mathrm{~g}$ sodium acetate (anhydrous) were added and mixed properly using vortex mixture for 1 minute. After mixing tubes were centrifuged at $2205 \mathrm{rcf}$ for 2 minutes. For clean-up, $6 \mathrm{~mL}$ supernatant transferred to $15 \mathrm{~mL}$ capacity polypropylene centrifuge tube containing $300 \mathrm{mg}$ of PSA and $900 \mathrm{mg}$ of $\mathrm{MgSO}_{4}$. The tubes were mixed well and centrifuged at $1125 \mathrm{rcf}$ for 2 minutes. Following this, an aliquot of $2 \mathrm{~mL}$ was drawn into glass tube and subsequently evaporated to dryness at $45^{\circ} \mathrm{C}$ under a gentle stream of nitrogen with Calipar life science make TurboVap. Finally, the volume of the samples was reconstituted to $2.0 \mathrm{~mL}$ with $n$-hexane: acetone $(\mathrm{v} / \mathrm{v}, 9: 1)$ for gas chromatographic analysis.

(b) Soil: Representative soil sample $(10 \pm 0.1 \mathrm{~g})$ was extracted with $20 \mathrm{~mL}$ acetonitrile in $50 \mathrm{~mL}$ capacity polypropylene centrifuge tube. The adsorbents $\mathrm{MgSO}_{4}(4.0 \mathrm{~g})$ and $\mathrm{NaCl}(1.0 \mathrm{~g})$ were added and followed by vigorous shaking on vortex mixture for 1 minute and centrifugation at $2205 \mathrm{rcf}$ for 2 minutes. Then, an aliquot of $10 \mathrm{~mL}$ was transferred to a $15 \mathrm{~mL}$ centrifuge tube containing $\mathrm{MgSO}_{4}(1.5 \mathrm{~g})$ and PSA $(0.25 \mathrm{~g})$ followed by centrifugation at $1125 \mathrm{rcf}$ for 2 minutes. Subsequently, an aliquot of $4 \mathrm{~mL}$ was transferred to the test tube and evaporated to dryness. Finally, the volume was made up to $2 \mathrm{~mL}$ using $n$-hexane: acetone $(9: 1, \mathrm{v} / \mathrm{v})$ and quantitative analysis were performed on GC-ECD.

\section{Instrumental parameters}

GC-ECD analysis

A gas chromatograph (TRACE GC ULTRA) equipped with electron capture detector (ECD) and TRIPLUS auto-sampler was used for quantitative analysis of profenofos and cypermethrin from sapota and soil sample. The chromatographic separation was performed on the capillary column (AB-5, 30m $\times 0.25 \mathrm{~mm}$ i.d., $0.25 \mu \mathrm{m} \mathrm{FT}$ ). The $1.0 \mu \mathrm{L}$ sample was injected under splitless mode into GC. Ultra-pure helium (99.999\%) gas was used as carrier gas at a flow rate of $1.0 \mathrm{ml} \mathrm{min}^{-1}$. The oven temperature was initially maintained at 220 ${ }^{\circ} \mathrm{C}$ for 4 minutes and programmed with the ramp of $15^{\circ} \mathrm{C} \mathrm{min}^{-1}$ to attain the final temperature of $290^{\circ} \mathrm{C}$ which was maintained for 4 minutes. Injector and detector temperatures were maintained at $230{ }^{\circ} \mathrm{C}$ and $300{ }^{\circ} \mathrm{C}$, respectively. The reference current of ECD was $1.0 \mathrm{nA}$. Under optimized parameters, the retention time (RT) of profenofos was 4.62 minute and cypermethrin was 8.43 minute which is shown in the chromatograms (Figure 3). The data were processed using the Xcalibur software (Thermo Scientific).

\section{Analytical method validation}

The method was performed and validated as per SANTE guidelines (SANTE, 2017) by optimizing various parameters. The linearity of profenofos and cypermethrin in solvent ( $n$-hexane: acetone; $9: 1, \mathrm{v} / \mathrm{v})$ were obtained using five calibration standards ranging from $0.01-0.1 \mathrm{mg} / \mathrm{kg}(0.01,0.025,0.05,0.075$ and 0.100 $\mathrm{mg} / \mathrm{kg}$ ). Five repetitive responses on GC-ECD for profenofos and cypermethrin at different concentrations were evaluated to establish the limit of detection (LOD) and the limit of quantification (LOQ) of the analytical method. LOD and LOQ were calculated using formula LOD $(\mathrm{mg} / \mathrm{kg})=$ (mean of standard deviation/Slope) $\times 3$ and LOQ $(\mathrm{mg} / \mathrm{kg})=($ mean of standard deviation/Slope $) \times 10$ (Patil et al. 2018). The accuracy and precision were observed through percent recovery and relative standard deviation (RSD) study for both insecticides. Three concentration levels of fortification for profenofos and cypermethrin (0.025 0.05 and 0.1 $\mathrm{mg} / \mathrm{kg})$ in sapota fruit and soil were used with seven replications $(\mathrm{n}=7)$.

\section{Health risk index (HRI)}

The residues obtained from sapota fruits subjected to spray of combi-product (Profenofos and cypermethrin) at standard dose as mentioned above collected on 0-20 days were used to work out the different Health risk indices (HRI). The estimated daily intake (EDI) was compared with the acceptable daily intake (ADI) (Wang et al., 2011). Estimated Daily Intake (EDI) is the ratio of the product of pesticide concentration $(\mathrm{mg} / \mathrm{kg})$ and the food consumption rate $(\mathrm{kg} / \mathrm{day})$ to the body weight of different groups of Indian population (e.g. $60 \mathrm{~kg}$ for Man and $55 \mathrm{~kg}$ for Woman). The quantity of average daily fruit intake considered for the calculation of EDI was $0.1 \mathrm{~kg} /$ person/day for adults (Anonymous, 2011). Health risk index (HRI) was 
calculated using the equation: Health risk Index (HRI) = EDI/ADI (European Food Safety Authority, 2007), where EDI is estimated daily intake and ADI is acceptable daily intake. ADI was considered $0.02 \mathrm{mg} / \mathrm{kg} \mathrm{bw}$ (body weight) for cypermethrin and $0.03 \mathrm{mg} / \mathrm{kg}$ bw for Profenofos (CODEX alimentarius, 2020). Health risk index more than 1 is considered as unsafe for human health (Darko and Akoto, 2008; Malhat et al., 2014) and Health Index (HI) <100\% represents an acceptable risk to human health (Malhat et al., 2017; Qin et al., 2020).

\section{Statistical analysis}

The dissipation of profenofos and cypermethrin in sapota was calculated by using Single First Order dissipation model using the equation $\mathrm{C}_{\mathrm{t}}=\mathrm{C}_{0} \mathrm{e}^{-\mathrm{kt}}$, Where $\mathrm{C}_{\mathrm{t}}$ is insecticide concentration at time $\mathrm{t}, \mathrm{C}_{0}$ is initial concentration, $\mathrm{k}$ is the rate constant. The residues data were statistically analysed according to Hoskins (1961) to compute the residual half-life (DT-50) and pre-harvest interval (PHI) e.g. waiting period.

\section{Results and Discussion}

\section{Method verification}

GC-ECD was used to obtain the linear dynamic range of the profenofos and cypermethrin by plotting graph between detector's response $\mathrm{v} / \mathrm{s}$ concentration. The linear dynamic range were recorded for both insecticides lie between 0.01 and $1.0 \mathrm{mg} / \mathrm{kg}$ with acceptable $\mathrm{R}^{2}$ values $(\geq 0.99)$ (Table 1$)$. Furthermore, recovery study for sapota fruit and soil were carried out at $0.025,0.05$, and $0.1 \mathrm{mg} / \mathrm{kg}$ levels taking five replications for each level. The profenofos recovery was in the range of $80.20-83.58 \%$ in sapota and $78.22-85.90 \%$ in soil at different fortification levels whereas these were recorded in the range of $88.74-104.22 \%$ and $91.12-99.47 \%$ in spota fruit and soil respectively for cypermethrin (Table 1). The maximum residue limit (MRL) values of profenofos and cypermethrin in sapota fruit are used 0.07 and $0.5 \mathrm{mg} / \mathrm{kg}$, respectively (CODEX alimentarius, 2020) for calculation of waiting period and risk assessment parameters. The respective LOD values of profenofos and cypermethrin in Sapota fruit obtained were 0.010 and $0.002 \mathrm{mg} / \mathrm{kg}$. While the LOQ values found were 0.030 and $0.006 \mathrm{mg} / \mathrm{kg}$, respectively (Table 1 ). The observed LOQ values of both pesticides were lower than MRL values fixed for sapota which specifies that the instrument was quite sensitive to accept the internationally acceptable standards of SANTE 2017 (Table 1). For accuracy, percent recoveries of profenofos and cypermethrin were ranged $80.20-83.58 \%$ and $88.74-104.22 \%$ in sapota fruit as well as $78.22-85.90 \%$ and 91.12-99.47\% in soil, respectively. The respective RSDs of profenofos and cypermethrin were ranged from 4.12 to $9.85 \%$ and $6.98-11.04 \%$ in sapota fruit and soil (Table 1).

Table 1 Method validation parameters of profenofos and cypermethrin residues in sapota fruit and soil

\begin{tabular}{|c|c|c|c|c|c|c|c|}
\hline SrNo. & Parameters & \multicolumn{2}{|c|}{ Particular } & \multicolumn{2}{|c|}{ Profenofos } & \multicolumn{2}{|c|}{ Cypermethrin } \\
\hline \multirow{3}{*}{1} & \multirow{3}{*}{$\begin{array}{l}\text { Linearity } \\
\quad(\mathrm{n}=5)\end{array}$} & \multicolumn{2}{|c|}{ Calibration concentration range } & \multicolumn{2}{|c|}{$0.01-0.1 \mathrm{mg} / \mathrm{kg}$} & \multicolumn{2}{|c|}{$0.01-0.1 \mathrm{mg} / \mathrm{kg}$} \\
\hline & & \multicolumn{2}{|c|}{ Regression equation } & \multicolumn{2}{|c|}{$y=66784 x-835.5$} & \multicolumn{2}{|c|}{$y=58519 x-2395$} \\
\hline & & \multicolumn{2}{|c|}{$\mathrm{R}^{2}\left\{\mathrm{R}^{2} \geq 0.99\right\}$} & \multicolumn{2}{|c|}{0.99} & \multicolumn{2}{|c|}{0.99} \\
\hline \multirow{2}{*}{2} & \multirow{2}{*}{$\begin{array}{c}\text { Sensitivity } \\
(\mathrm{n}=5)\end{array}$} & \multicolumn{2}{|c|}{$\mathrm{LOD}(\mathrm{mg} / \mathrm{kg})$} & \multicolumn{2}{|c|}{0.010} & \multicolumn{2}{|c|}{0.002} \\
\hline & & \multicolumn{2}{|c|}{$\mathrm{LOQ}(\mathrm{mg} / \mathrm{kg})$} & \multicolumn{2}{|c|}{0.030} & \multicolumn{2}{|c|}{0.006} \\
\hline \multirow{4}{*}{3} & \multirow{4}{*}{$\begin{array}{c}\text { Accuracy } \\
(\mathrm{n}=7)\end{array}$} & \multirow{4}{*}{$\begin{array}{c}\text { Percent } \\
\text { Recovery } \\
{[70-120 \%]}\end{array}$} & Fortified level $(\mathrm{mg} / \mathrm{kg})$ & Sapota fruit $(\%)$ & Soil (\%) & Sapota fruit (\%) & Soil (\%) \\
\hline & & & 0.025 & $83.11 \pm 4.59$ & $80.96 \pm 4.47$ & $104.22 \pm 9.24$ & $98.21 \pm 13.24$ \\
\hline & & & 0.05 & $80.20 \pm 2.27$ & $78.22 \pm 2.26$ & $98.41 \pm 7.65$ & $99.47 \pm 10.67$ \\
\hline & & & 0.1 & $83.58 \pm 7.32$ & $85.90 \pm 9.30$ & $88.74 \pm 3.98$ & $91.12 \pm 3.24$ \\
\hline \multirow{4}{*}{4} & \multirow{4}{*}{$\begin{array}{c}\text { Precision } \\
\quad(n=7)\end{array}$} & \multirow{4}{*}{$\begin{array}{c}\text { RSD } \\
{[\leq 20 \%]}\end{array}$} & Fortified level $(\mathrm{mg} / \mathrm{kg})$ & Sapota fruit (\%) & Soil (\%) & Sapota fruit (\%) & Soil (\%) \\
\hline & & & 0.025 & 6.86 & 9.85 & 8.78 & 6.98 \\
\hline & & & 0.05 & 5.73 & 6.53 & 7.16 & 9.40 \\
\hline & & & 0.1 & 4.12 & 7.27 & 11.04 & 10.03 \\
\hline
\end{tabular}

$\mathrm{R}^{2}$ : correlation coefficient; LOQ: Limit of Quantitation; LOD: Limit of detection; \pm SD: Standard deviation; RSD: Relative standard deviation; Values given in parenthesis \{\} and [ ] is the standard acceptance criteria as per SANTE, 2017 


\section{Dissipation study}

The residues of profenofos in sapota fruit obtained on 0 days were 0.268 and $0.471 \mathrm{mg} / \mathrm{kg}$ at standard and double to the standard dose, respectively (Table 2 and Figure 3). In case of control (only spray of water), both pesticides residues were not detected (Figure 3 ). Profenofos residues declines gradually and were BQL on the $30^{\text {th }}$ day at the SD, while these were $0.023 \mathrm{mg} / \mathrm{kg}$ at $2 \times \mathrm{SD}$. The half-life value worked out for profenofos in sapota were 5.65 and 7.34 days and the waiting period was 13.82 and 22.24 days for $S D$ and $2 \times S D$, respectively (Table 2).

Although, the residues of cypermethrin were dissipated more rapidly than profenofos yet these were persisted up to 7 days. In sapota fruit, the residues of cypermethrin obtained on 0 day were 0.014 and 0.019 $\mathrm{mg} / \mathrm{kg}$ at $\mathrm{SD}$ and $2 \times \mathrm{SD}$, respectively (Table 2 ). Cypermethrin residues were BQL on $10^{\text {th }}$ day after last application for both doses. The half-life value worked out for cypermethrin residues in sapota fruit were 3.27 and 4.43 days for $S D$ and $2 \times S D$, respectively. The waiting period worked out for cypermethrin was 5.16 days at SD and 8.42 days at $2 \times \mathrm{SD}$ (Table 2). Similar work has been done by Solanki et al. (2019) using combiproduct of chlorpyrifos and cypermethrin in sapota and have reported waiting period of 4 to 5 days used as combi-product. Likewise, Gupta et al. (2011) have studied the persistence of the chlorpyrifos, profenofos and cypermethrin in tomato using pre-mix formulation (Chlorpyriphos 50\% + Cypermethrin 5\%) and (Profenofos $40 \%$ + Cypermethrin 5\%) and found that in pre-mix formulation the residues of profenofos persisted up to 715 days while the residues of cypermethrin and chlorpyrifos persist up to 0-7 days only.

Table 2 Residues and percent dissipation of profenofos and cypermethrin in/on sapota fruit and soil ( $\mathrm{n}=3$ )

\begin{tabular}{|c|c|c|c|c|c|}
\hline \multirow{3}{*}{$\begin{array}{l}\text { Days after } \\
\text { application }\end{array}$} & \multicolumn{5}{|c|}{ Average residues $(\mathrm{mg} / \mathrm{kg})$ in sapota fruit } \\
\hline & \multirow[b]{2}{*}{ Control } & \multicolumn{2}{|c|}{ Profenofos } & \multicolumn{2}{|c|}{ Cypermethrin } \\
\hline & & $\begin{array}{l}1162 \text { g a.i. ha }{ }^{-1} \\
\text { (SD) })^{a}\end{array}$ & $\begin{array}{l}2324 \text { g a.i. ha }{ }^{-1} \\
(2 \times S D)^{b}\end{array}$ & $\begin{array}{l}106 \text { g a.i. ha }^{-1} \\
\text { (SD) }\end{array}$ & $\begin{array}{l}212 \text { g a.i. ha }{ }^{-1} \\
(2 \times S D)^{b}\end{array}$ \\
\hline $0(2 \mathrm{~h})$ & ND & $\begin{array}{l}0.268 \\
(0.00)\end{array}$ & $\begin{array}{l}0.471 \\
(0.00)\end{array}$ & $\begin{array}{l}0.014 \\
(0.00)\end{array}$ & $\begin{array}{l}0.019 \\
(0.00)\end{array}$ \\
\hline 1 & ND & $\begin{array}{l}0.244 \\
(8.94) \\
\end{array}$ & $\begin{array}{l}0.455 \\
(3.49) \\
\end{array}$ & $\begin{array}{c}0.012 \\
(13.48) \\
\end{array}$ & $\begin{array}{c}0.015 \\
(23.58) \\
\end{array}$ \\
\hline 3 & ND & $\begin{array}{c}0.212 \\
(20.74) \\
\end{array}$ & $\begin{array}{c}0.259 \\
(44.96) \\
\end{array}$ & $\begin{array}{c}0.009 \\
(37.08) \\
\end{array}$ & $\begin{array}{c}0.013 \\
(33.80) \\
\end{array}$ \\
\hline 5 & ND & $\begin{array}{c}0.170 \\
(36.53)\end{array}$ & $\begin{array}{c}0.232 \\
(50.84)\end{array}$ & $\begin{array}{c}0.006 \\
(65.49) \\
\end{array}$ & $\begin{array}{c}0.009 \\
(50.14)\end{array}$ \\
\hline 7 & ND & $\begin{array}{c}0.109 \\
(59.47) \\
\end{array}$ & $\begin{array}{c}0.179 \\
(61.95) \\
\end{array}$ & $\mathrm{BQL}$ & $\begin{array}{c}0.006 \\
(70.99) \\
\end{array}$ \\
\hline 10 & ND & $\begin{array}{c}0.058 \\
(78.42)\end{array}$ & $\begin{array}{c}0.143 \\
(69.70)\end{array}$ & BQL & $\mathrm{BQL}$ \\
\hline 20 & ND & $\begin{array}{c}0.027 \\
(90.07)\end{array}$ & $\begin{array}{c}0.075 \\
(84.02)\end{array}$ & BQL & BQL \\
\hline 30 & ND & BQL & $\begin{array}{c}0.023 \\
(95.06)\end{array}$ & BQL & BQL \\
\hline 45 & ND & BQL & BQL & BQL & BQL \\
\hline Dissipation equation & - & $\mathrm{y}=-0.053 \mathrm{x}+1.435$ & $y=-0.040 x+1.608$ & $y=-0.09 x+1.173$ & $y=-0.067 x+1.271$ \\
\hline $\begin{array}{c}\text { Correlation coefficient } \\
\left(\mathrm{R}^{2}\right)\end{array}$ & - & 0.96 & 0.99 & 0.97 & 0.98 \\
\hline Half-life (days) & - & 5.65 & 7.34 & 3.27 & 4.43 \\
\hline Waiting period (days) & - & 13.82 & 22.24 & 5.16 & 8.42 \\
\hline \multicolumn{6}{|c|}{ Average residues $(\mathrm{mg} / \mathrm{kg})$ in Soil } \\
\hline $0(2 \mathrm{~h})$ & ND & 0.080 & 0.230 & BQL & BQL \\
\hline 30 & ND & BQL & BQL & BQL & BQL \\
\hline Harvest time & ND & $\mathrm{BQL}$ & BQL & BQL & BQL \\
\hline
\end{tabular}

a: Standard dose; b: Double to the Standard dose; BQL: Below quantitation limit (<LOQ); Values given in parenthesis () represents percent degradation of pesticide residues over residues obtained on 0 day ( 2 hrs after application); ND: Not Detected 
The profenofos residues recovered in soil samples after insecticide application on 0 days was 0.08 and $0.23 \mathrm{mg} / \mathrm{kg}$ for SD and $2 \times \mathrm{SD}$ whereas on $30^{\text {th }}$ day profenofos residues was BQL. Cypermethrin residues were found below the detection level on first and last day of the sampling for both the applied doses (Table 2). Mukherjee et al. (2012) has also reported that the residues of the profenofos persisted up to 7 days in the soil while the residues of chlorpyrifos and cypermethrin were not even detected on 0 day from the soil. More or less similar half-life value of profenofos in mulberry leaves was reported by Paramasivam et al. (2012). In the present study, the effective waiting period worked out for the combi-product is slightly higher e.g. 14 days than the individual insecticide.
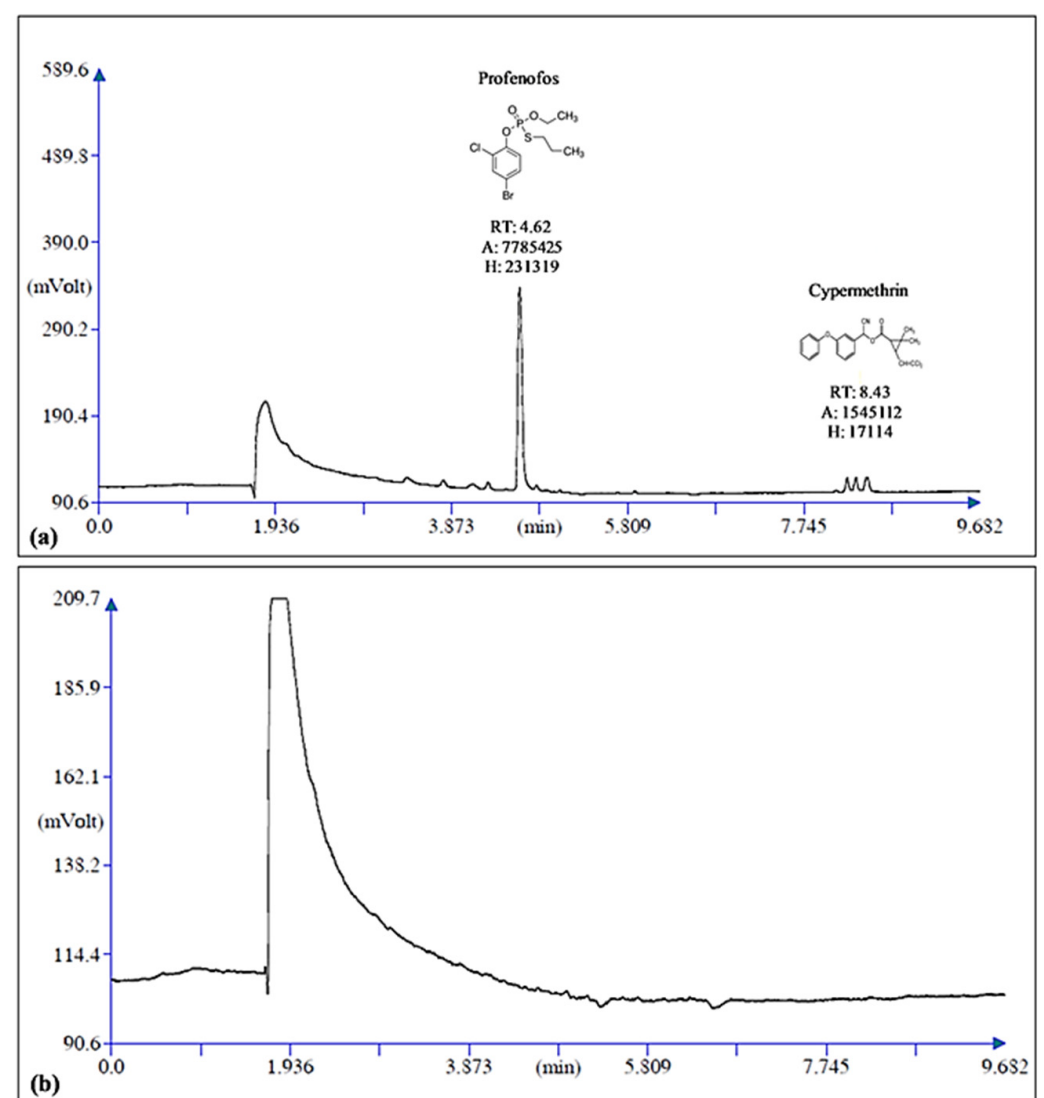

(b)

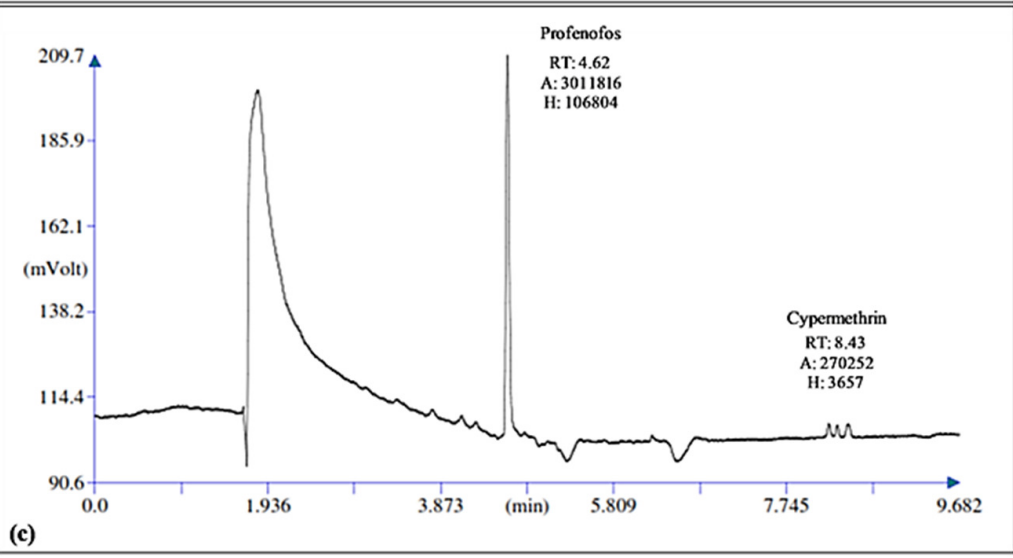

Figure 3. GC-chromatogram of profenofos and cypemethrin on GC-ECD (a) at standard $0.05 \mathrm{mg} / \mathrm{kg}$ (b) in control and (c) in sapota fruit sample at standard dose (SD) 


\section{Health risk assessment analysis}

Generally, ripened sapota fruit is preferred by consumers but the unripe sapota fruits are also used to prepare the wafers and chips etc. Pesticides are a major part among different chemicals applied on these food products. Injudicious use of pesticides on food crops leads to unwanted residues, which may constitute barriers to exporters and domestic consumptions when they exceed maximum residue limit (MRL). Therefore, health risk estimations were studied based on pesticide residues detected in sapota fruits.

The health risk index (HRI) was estimated by dividing the EDI ( $\mathrm{mg} \mathrm{kg}^{-1} /$ day) by their corresponding values of acceptable daily intakes (ADI) for agricultural and veterinary chemicals (Anonymous, 2005). The average values of individual body weights involving different age groups in India are listed according to the official dietary guideline for Indians (National Institute of Nutrition, 2011). Cumulative estimated health risk index values as well as Health Index (\%) of profenofos and cypermethrin residues recorded at SD and $2 \times S D$ are presented in Table 3. Thus, it reflects that under the tropical agro-climatic conditions from 0 days after spray at both doses, the HRI values are lower than 1 and $\mathrm{HI} \%$ are less than $100 \%$. It indicates that the combiproduct will not cause any adverse effect after consumption of sapota fruits. Therefore, the consumption of sapota fruits laced with combi-product of profenofos and cypermethrin at standard dose with an observed waiting period of 14 days are safer as their HRI values are lower than 1.

Table 3 Health risk assessment of pre-mix formulation of profenofos and cypermethrin residues in sapota fruit for different groups of Indian consumers

\begin{tabular}{|c|c|c|c|c|c|c|c|c|c|c|c|}
\hline \multirow{4}{*}{ Group } & \multirow{4}{*}{$\begin{array}{l}\text { Particulars } \\
\text { with age }\end{array}$} & \multirow{4}{*}{$\begin{array}{c}\text { Food } \\
\text { consumption } \\
\text { (g/day) }\end{array}$} & \multirow{4}{*}{$\begin{array}{c}\text { Body } \\
\text { weight } \\
(\mathrm{kg})\end{array}$} & \multicolumn{8}{|c|}{ Health risk assessment } \\
\hline & & & & \multicolumn{4}{|c|}{ SD } & \multicolumn{4}{|c|}{$2 \times \mathrm{SD}$} \\
\hline & & & & $\mathrm{P}^{\mathrm{a}}$ & $C^{b}$ & & & $\mathrm{P}^{\mathrm{a}}$ & $\mathrm{C}^{\mathrm{b}}$ & & C) ${ }^{c}$ \\
\hline & & & & $\mathrm{HRI}^{\mathrm{d}}$ & $\mathrm{HRI}^{\mathrm{d}}$ & $\mathrm{HRI}^{\mathrm{d}}$ & $\% \mathrm{H}^{\mathrm{c}}$ & HRI $^{d}$ & $\mathrm{HRI}^{\mathrm{d}}$ & $\mathrm{HRI}^{\mathrm{d}}$ & $\% \mathrm{HI}^{\mathrm{c}}$ \\
\hline \multirow{3}{*}{ Children } & $1-3$ years & 30 & 12.90 & 0.07 & 0.00 & 0.07 & 7.47 & 0.12 & 0.01 & 0.13 & 12.91 \\
\hline & 4-6 years & 30 & 18.00 & 0.05 & 0.00 & 0.05 & 5.35 & 0.09 & 0.00 & 0.09 & 9.25 \\
\hline & 7-9 years & 60 & 25.10 & 0.04 & 0.00 & 0.04 & 3.84 & 0.06 & 0.00 & 0.07 & 6.63 \\
\hline Boys & $10-12$ years & 60 & 34.30 & 0.03 & 0.00 & 0.03 & 2.81 & 0.05 & 0.00 & 0.05 & 4.85 \\
\hline Girls & $10-12$ years & 60 & 35.00 & 0.03 & 0.00 & 0.03 & 2.75 & 0.04 & 0.00 & 0.04 & 4.76 \\
\hline Boys & $13-15$ years & 75 & 47.60 & 0.02 & 0.00 & 0.02 & 2.02 & 0.03 & 0.00 & 0.03 & 3.50 \\
\hline Girls & $13-15$ years & 60 & 46.60 & 0.02 & 0.00 & 0.02 & 2.07 & 0.04 & 0.00 & 0.04 & 3.57 \\
\hline Boys & $16-18$ years & 90 & 55.40 & 0.02 & 0.00 & 0.02 & 1.74 & 0.03 & 0.00 & 0.03 & 3.01 \\
\hline Girls & 16-18 years & 75 & 52.10 & 0.02 & 0.00 & 0.02 & 1.85 & 0.03 & 0.00 & 0.03 & 3.20 \\
\hline \multirow{3}{*}{ Man } & Sedentary work & 75 & \multirow{3}{*}{60.00} & \multirow{3}{*}{0.01} & \multirow{3}{*}{0.00} & \multirow{3}{*}{0.02} & \multirow{3}{*}{1.61} & \multirow{3}{*}{0.03} & \multirow{3}{*}{0.00} & \multirow{3}{*}{0.03} & \multirow{3}{*}{2.78} \\
\hline & Moderate work & 90 & & & & & & & & & \\
\hline & Heavy work & 120 & & & & & & & & & \\
\hline \multirow{3}{*}{ Woman } & Sedentary work & 60 & \multirow{3}{*}{55.00} & \multirow{3}{*}{0.02} & \multirow{3}{*}{0.00} & \multirow{3}{*}{0.02} & \multirow{3}{*}{1.75} & \multirow{3}{*}{0.03} & \multirow{3}{*}{0.00} & \multirow{3}{*}{0.03} & \multirow{3}{*}{3.03} \\
\hline & Moderate work & 75 & & & & & & & & & \\
\hline & Heavy work & 90 & & & & & & & & & \\
\hline
\end{tabular}

SD: Standard dose; $2 \times$ SD: Double to the Standard dose; a: Profenofos; b: Cypermethrin; c: Cumulative (Profenofos+Cypermethrin); d: Health Risk Index; e: Percent Health Index

\section{Conclusions}

Profenofos and cypermethrin were moderately persisted in the sapota when applied as a pre-mix formulation profenofos $40 \%+$ cypermethrin $4 \%$ (44EC). The residue of profenofos in sapota fruits persisted upto 20 days while these were 7 days in cypermethrin at Standard dose. The individual waiting period worked out for profenofos and cypermethrin was 13.82 and 5.16 days at SD. Therefore, it is suggested the observation of 14 days waiting period, when profenofos and cypermethrin applied as combi-product. The findings of the dietary risk assessment study also strengthen those 14 days waiting period is sufficient to nullify the toxic effect 
of these pesticides to the consumers as the HRI values were below 1 from 0 day at SD. This implies that spray of combi-product profenofos $40 \%$ and cypermethrin $4 \%$ at standard dose do not pose any health risk to consumers when 14 days waiting period is observed.

\section{Authors' Contributions}

Conceptualization of research (SS and VS); Designing of the experiments (SS); Contribution of experimental materials (TA); Supervision of field/lab experiments and methodology (KG and NP); data collection, analysis and interpretation (VS, KG and RK); Writing - original draft (RK and NP), review and editing manuscript (VS and KG). All authors read and approved the final manuscript.

\section{Acknowledgements}

Authors are grateful to all the personnel who have directly or indirectly contributed to compilation and preparation of the manuscript. Authors are also thankful to Head of Regional Horticultural Research Station, Navsari Agricultural University, Navsari as well as National Agricultural Higher Education Project-Centre for Advanced Agricultural Science and Technology (NAHEP-CAAST) for providing necessary support to perform this study.

\section{Conflict of Interests}

The authors declare that there are no conflicts of interest related to this article.

\section{References}

Anonymous (2018). Final estimate of area and production of horticulture crops. National Horticultural Board, Gurgaon, India (2016-2017). http://nhb.gov.in/statistics/State_Level/2016-17(Final).pdf

Anonymous (2019). Source: National Horticulture Board http://apeda.in/agriexchange/India\%20Production/India_Productions.aspx?'cat=fruit\&hscode=1059

Anonymous (2005). Acceptable daily intakes for agricultural and veterinary chemicals. Australian Government, Office of chemical safety. Department of Health and Ageing pp 1-113.

Anonymous (2011). Dietary guidelines for Indian - a manual. National Institute of Nutrition, ICMR publication. pp 1139.

Butani DK (1979). Insect and Fruits. Periodical Expert Book Agency, Delhi.

CODEX Alimentarius International Food Standards (2020). http://www.fao.org/fao-who-codexalimentarius/codextexts/dbs/pestres/pesticides/en

Darko G, Akoto O (2008). Dietary intake of organophosphorus pesticide residues through vegetables from Kumasi, Ghana. Food and Chemical Toxicology 46(12):3703-6. https://doi.org/10.1016/j.fct.2008.09.049

European Food Safety Authority (2007). The EFSA's $7^{\text {th }}$ scientific colloquium summary report -cumulative risk assessment of pesticides to human health: The Way Forward. Retrieved 2020 June 25 from http://www.efsa.europa.eu/en/supporting/pub/117e.htm

Ghosh SN (2014). Tropical and sub-tropical fruit crops: crop improvement and varietal wealth. JAYA Publishing House.

Gupta S, Gajbhiye VT, Sharma RK, Gupta RK (2011). Dissipation of cypermethrin, chlorpyriphos and profenofos in tomato fruits and soil following application of pre-mix formulations. Environmental Monitoring and Assessment 174:337-345. https://doi.org/org/10.1007/s10661-010-1461-0

Hoskin WM (1961). Mathematical treatment of the rate of loss of pesticide residues. FAO Plant Protection Bulletin 9:163-168. https://doi.org/10.12691/env-2-3-2 
Jhala RC, Shah AH, Patel CB, Patel SH (1986). Population dynamics of some insect pests of sapota in South Gujarat. Gujarat Agricultural Universities Research Journal 11:69-71.

Malhat FM, El Sharkawi HM, Loutfy NM, Ahmed MT (2014). Field dissipation and health hazard assessment of Fenhexamid on Egyptian grapes. Toxicological and Environmental Chemistry 96(5):722-729. https://doi.org/10.1080/02772248.2014.980130

Malhat F, Boulange J, Abdelraheem E, Abd Allah O, Abd El-Hamid R, ... Abd El-Salam S (2017). Validation of QuEChERS based method for determination of fenitrothion residues in tomatoes by gas chromatography-flame photometric detector: Decline pattern and risk assessment. Food Chemistry 229:814-819. https://doi.org/10.1016/j.foodchem.2017.03.017

Mukherjee I, Kumar A, Kumar A (2012). Persistence behaviour of combination mix crop protection agents in/on eggplant fruits. Bulletin of Environmental Contamination and Toxicology 88:338-343. https://doi.org/10.1007/s00128-011-0457-y

Paramasivam M, Chandrasekaran S, Karthik P, Naik HR, Thangachamy P, Mahalingam CA (2012). Persistence and dissipation of dichlorvos and profenofos on mulberry leaves. Madras Agricultural Journal 99(7-9):583-585.

Patil VM, Singh S, Patel KG, Patel ZP (2018). Effect of sun drying and grinding on the residues of six insecticides in chili fruits. Pesticide Research Journal 30(2):140-6. https://doi.org/10.5958/2249-524X.2018.00023.7

Qin X, Luo X, Han J, Chen Y, Zhang K, Hu D (2020). Residual determination of pyrethrins in Lycium barbarum (goji) by GC-MS/MS and a dietary risk assessment of Chinese goji consumption. Food Additives and Contaminants 37(3):478-487. https://doi.org/10.1080/19440049.2019.1707295

Sharma KK (2013). Pesticide residues analysis manual. IARI, New Delhi, pp 92-94.

Shirol AM, Kanamadi VC, Duragannavar MP, Thammaiah N, Baragimath SM (2009). Studies on quality parameters of sapota cultivars. The Asian Journal of Horticulture 5(3).

Shukla A, Patel PR (2011). Bionomics of chiku moth, Nephopteryx eugraphella Ragonot (Pyralidae:Lepidoptera) on sapota. Pest Management in Horticultural Ecosystems 17(1):6-10.

Solanki VH, Singh S, Gandhi KD, Patel KG, Patel KN (2019). Persistence behaviour of pre-mix formulation of profenophos and cypermethrin in/on sapota fruit. International Journal of Current Microbiology and Applied Sciences 8(1):1250-1260. https://doi.org/10.20546/ijcmas.2019.801.132

Suryavanshi SS, Patel BR (2009). Evaluation of different insecticides against sapota bud borer, Anarsia achrasella Bardley. Karnataka Journal of Agricultural Sciences 22(3):722-723.

Thumar Rasiklal K, Borad Parbhatbhai K, Dabhi Manishkumar R, Korat Dhirubhai M (2015). Effect of weather parameters on activity of chiku bud borer, Anarsia achrasella Bradley on sapota. African Journal of Agricultural Research 10(11):1192-1196. https://doi.org/10.5897/AJAR2013.6777

Ujagir R, Byrne OM (2009). 18 insect pests and their management. The Lentil 282:47-48. http://dx.doi.org/10.1079/9781845934873.0282

Wang HS, Sthiannopkao S, Du J, Chen Z J, Kim KW, Yasin MSM, Hashim JH, Wong CKC, Wong MH (2011). Daily intake and human risk assessment of organochlorine pesticides (OCPs) based on Cambodian market basket data. Journal of Hazardous Materials 192:1441-1449. https://doi.org/10.1016/j.jhazmat.2011.06.062

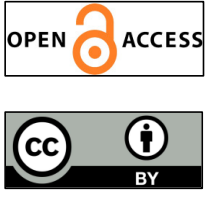

The journal offers free, immediate, and unrestricted access to peer-reviewed research and scholarly work. Users are allowed to read, download, copy, distribute, print, search, or link to the full texts of the articles, or use them for any other lawful purpose, without asking prior permission from the publisher or the author.

License - Articles published in Notulae Scientia Biologicae are Open-Access, distributed under the terms and conditions of the Creative Commons Attribution (CC BY 4.0) License.

(c) Articles by the authors; SHST, Cluj-Napoca, Romania. The journal allows the author(s) to hold the copyright/to retain publishing rights without restriction. 